\title{
TTR
}

Traduction, terminologie, re?daction

\section{Feminist Translation: Contexts, Practices and Theories}

\section{Luise von Flotow}

Volume 4, numéro 2, 2e semestre 1991

Traduire la théorie

URI : https://id.erudit.org/iderudit/037094ar

DOI : https://doi.org/10.7202/037094ar

Aller au sommaire du numéro

Éditeur(s)

Association canadienne de traductologie

ISSN

0835-8443 (imprimé)

1708-2188 (numérique)

Découvrir la revue

Citer cet article

von Flotow, L. (1991). Feminist Translation: Contexts, Practices and Theories. TTR, 4(2), 69-84. https://doi.org/10.7202/037094ar d'utilisation que vous pouvez consulter en ligne.

https://apropos.erudit.org/fr/usagers/politique-dutilisation/ 


\section{Feminist Translation : Contexts, Practices and Theories}

\section{Luise von Flotow}

Or, How to translate "Ce soir j' entre dans l' histoire sans relever ma jupe."1

I would like to open this essay with a specific translation problem from La Nef des sorcieres ${ }^{2}$, a dramatic work produced by a group of feminist writers in Quebec in 1976. The problem is how to translate the following line: "Ce soir, $\mathrm{j}$ 'entre dans l'histoire sans relever ma jupe." There are two translators available for the job: one with more or less traditional views on the importance of "fidelity" and equivalence in translation, who believes that a translator's work should be seen through, and not heard about. The other is a feminist translator. The more traditional translator renders this line from the play as follows:

1. Several oral versions of this essay have been presented: at the CIEF (Conseil International d'Etudes Francophones) conference in Martinique, 1990, and at the CATS (Canadian Association for Translation Studies) meeting in Kingston, Ontario, in 1991.

2. Brossard, N., France Théoret, et al., La Nef des sorcières, (Montréal, Quinze, 1976) was written by a number of women authors and actresses. It opened on March 5, 1976 at the Théâtre du Nouveau-Monde in Montreal. The two translators referred to here are respectively, David Ellis and Linda Gaboriau. Gaboriau's translation of Brossard's text, "L'Écrivain," was published as "The Writer" in Fireweed, 5-6, 1979-80. 
"this evening I'm entering history without pulling up my skirt." This seems a perfectly adequate, idiomatic version of the source language text, although I would prefer the more colloquial "without hiking up my skirt." The feminist translator, on the other hand, translates as follows: "this evening I'm entering history without opening my legs." Is this a shocking, unacceptable over-translation, a deliberate over-interpretation of the original text? Is the translator taking outrageous liberties with a line that is relatively anodine in the French? Is she being deliberately sensationalist?

I should add here that this example has been used several times before, but is still appropriate as an illustration of a current practice in Canadian translation. I took it directly from an article by Barbara Godard, one of Canada's first feminist translators, and she took it from an earlier article by Évelyne Voldeng'; a tight circle, which may also go to show how few literary translators and critics in Canada are sensitive to feminist issues. It is all the more noteworthy then, that a small number of Canadian translators should have the effrontery to proclaim an anti-traditional, aggressive and creative approach to translation which they call feminist translation.

My exploration of this translation practice is not concerned with which of the two translations given above is better, or more appropriate, or more faithful. Instead, I am interested in the context, the practices and the underlying theories that make the feminist translation "without opening my legs" acceptable, even desirable. In commenting on this obvious over-translation, Godard, for example, praised its "shock effect," and the fact that it makes explicit what is implicit in the feminist text - "the repossession of the word by women, and the naming of the life of the body as experienced by women" (Godard, 1984, p. 14). I find the growing importance of this type of translation and its increasing visibility intriguing, and potentially invigorating as a new approach to the work of translation.

I base my claim for the importance of the phenomenon of feminist translation in Canada on two factors: the increasing numbers

3. B. Godard, "Translating and Sexual Difference" in Resources for Feminist Research, Vol. 13, No. 3, 1984, pp. 13-16. 
of English translations self-consciously describing themselves as feminist, and on the increasing number of feminist texts being translated in Canada today. In the last few years almost all of Nicole Brossard's radical feminist work has been translated by Barbara Godard, Marlene Wildeman and Fiona Strachan, and her Désert mauve has just been published in translation by Susanne de Lotbinière-Harwood ${ }^{4}$. Similarly, France Theoret's early work is coming out shortly in a collection, The Tangible Word, translated by Godard, and I have just translated her L'Homme qui peignait Staline'. A first volume of Madeleine Gagnon's work has appeared in translation by Howard Scott, the only male who describes himself as a feminist translator, and Louky Bersianik's L'Euguelionne is being re-translated by Scott ${ }^{6}$. And finally, Lise Gauvin's Lettres d' une autre has been deliberately turned into a feminist text in its translated, and prize-winning, English version by de

4. The following "radical feminist" books by Nicole Brossard have appeared in Canadian translation: These Our Mothers (Toronto, Coach House, 1983), Lovhers (Montreal, Guernica, 1987) and Picture theory (Montreal, Guernica, 1991) translated by Barbara Godard, Surfaces of Sense (Toronto, Coach House, 1989), translated by Fiona Strachan, The Aerial Letters (Toronto, Women's Press, 1988) translated by Marlene Wildeman, and Mauve Desert by Susanne de LotbinièreHarwood.

5. Theoret's early work will be published in a translation by Barbara Godard The Tangible Word (Montreal, Guemica Press, 1991). My translation of L'Homme qui peignait Staline was published by Mercury Press, Stratford, Ont. in 1991.

6. Howard Scott has published Lair (Toronto, Coach House, 1989) a translation of Madeleine Gagnon's Antre, and is preparing a new translation of Louky Bersianik's L'Euguelionne. 
Lotbinière-Harwood?. Almost invariably these publications are prefaced by remarks that describe the work as feminist translation.

\section{Contexts}

It is evident from the above that recent Quebec writing is at the root of this phenomenon, and I would like to quickly sketch out the cultural and social contexts that underlie it. Feminist translation seems to have developed as a method of translating the focus on and critique of "patriarchal language" by feminist writers in Quebec. In the late 1970s and early 1980s the Quebec writers I mentioned above, among others, were producing work that was highly experimental, and constituted efforts to attack, deconstruct, or simply bypass the conventional language they perceived as inherently misogynist. In the words of one critic of the period: "Les femmes injectent un sang neuf [...] et le déplacement du propos s'effectue autant dans le trajet que dans le projet de leurs créations (Sabourin, 1985, p. 129). If we cursorily define their "projet" as the elaboration of an "écriture au féminin," a feminist literary culture, then their "trajet" was an attack on conventional language - "le déplacement du propos."

These writers' texts were thus often oriented around formalist inquiry into the materiality of language, a tendency remaining from Quebec's earlier modernite. They were concerned with research into the etymology of conventional vocabulary and its deconstruction. They explored women's experiences that had not been put into words before, and tried to write "l'inédit"s. They sought to create a new idiom with which to express these experiences of the body, and write a women's utopia. The silent " $e$ " that marks the female gender in French became

7. Susanne de Lotbinière-Harwood has published translations of short texts by Nicole Brossard, as well as Lise Gauvin's Letters from Another (Toronto, Women's Press, 1989). She is also working on translating Gail Scott's Heroine into French, a process that made her base a recent lecture on the need for women to re-appropriate the word "con" in French.

8. "Inédit" is a privileged term in Brossard's writing referring to that which cannot be inscribed for lack of appropriate language. 
an important element in the critique of the masculine as a generic term; it was exploited as a mutant element with which neologisms and puns could be developed to parody and attack conventional language. Other strategies included the fragmentation of language, the disregard for grammatical or syntactical structures and the dismantling of individual words in order to examine their concealed meanings: Brossard's use of the word "de-lire" to mean both delirious and uncontrolled expression of women's realities and fantasies as well as the process of un-reading - DÉ-LIRE - or reading against the grain is a good example of this work on language.

Bersianik used another approach. Her etymological critique of conventional language pervades L'Euguelionne and she consistently manipulates language to parody patriarchal "knowledge." For example, her critique of the dictionary definition of the word "virile," which describes characteristics such as energy, activity, and courage as typical of men both reveals the arrogance of conventional knowledge and shows how easily she too can manipulate language:

un peu de modestie, messieurs les Virils. N'oubliez pas que le mot "verge" qui veut dire "baguette" a donné le diminutif "virgule"... (Bersianik, 1976, p. 356)

These are only two of the many different approaches taken by Quebec feminist writers in the 1970s and early 1980s to wreck the power of conventional discourse. Despite their different strategies, politics and personalities, they shared the general feeling that conventional and prescriptive "patriarchal language" had to be undone in order for women's words to develop, find a space and be heard.

The translation of these texts from Quebec began in the late-1970s with two feminist plays La Nef des sorcieres and Les Fées ont soif ${ }^{9}$. The anthology The Story so far ${ }^{10}$ edited by Brossard was

9. Denise Boucher, Les Fées ont soif (Montréal, Éditions Intermède, 1978) was translated as The Fairies are thirsty (Vancouver, Talonbooks, 1982). 
another important milestone, and gradually the corpus of translated feminist work from Quebec came to include conference texts, work presented at trans-Canadian women writers' meetings and finally complete books. Feminist translation is thus a direct spin-off from the experimental work by Quebec women writers; it is a phenomenon intimately connected to a specific writing practice in a specific ideological and cultural environment, the result of a specific social conjuncture. It is an approach to translation that has appropriated and adapted many of the techniques and theories that underlie the writing it translates.

\section{Practices}

There are numerous strategies used in feminist translation of which I will discuss only three here - supplementing, prefacing and footnoting, and "hijacking." Suffice it to say as a brief introduction, that the feminist translator, following the lead of the feminist writers she translates, has given herself permission to make her work visible, discuss the creative process she is engaged in, collude with and challenge the writers she translates.

\section{Supplementing}

Since "patriarchal language" and its institutions govern most aspects of conventional language, whether it is English, French or any other language, translators who work from Quebecois feminist texts into English have had to turn the critique of one language into the critique of another. Howard Scott's essay on translating Bersianik makes this clear (Scott, 1984). He did not want to "convey to the English reader what Bersianik says about French, he says, but rather adapt her message to English, and show how the English language is sexist" - pareil, mais autrement. Concretely, this means serious interference with the text. Supplementing, as we know from Benjamin's text, "Die Aufgabe des Ubersetzers," is one of the most positive aspects of translation. It is the aspect I always keep in mind when I wrestle with apparently

10. Nicole Brossard, ed. Les Stratégies du réel, translated as The Story so far, (Toronto, Coach House, 1979) with a number of different translators. 
untranslatable texts. According to Benjamin the source text is supplemented by its translation, matured, developed, and given an afterlife. This is precisely what happens with supplementation in feminist translation, with the difference that the feminist translator is conscious of her political role as a mediator, whereas Benjamin seems to conceive of a translation, or any work of art for that matter, as apolitical and not primarily destined for an audience.

Supplementing in feminist translation is a strategy which may explain the "over-translation" of the "without opening my legs" example above. It compensates for the differences between languages, or constitutes "voluntarist action" on the text. For even if English doesn't have exactly the same problems of gender or etymology, there are other places in the text where a similar déplacement of language can be carried out. There is a good example in Scott's translation of Bersianik's L'Euguélionne. In a text where the politics of abortion are held up for scrutiny, the following line occurs:

"Le ou la coupable doit être punie.."

The extra "e" on the past participle "puni" clearly indicates that it is the woman who is punished for aborting. But this subtlety is not directly transferable into English which lacks gender agreements. Scott's "voluntarist" solution supplements this particular lack in English and reads as follows :

"The guilty one must be punished, whether she is a man or a woman."

This feminist translator thus recoups certain losses by intervening in, and supplementing another part of the text. He also supplements the original text by making its critique of language apply to English, and meaningful to an English-speaking readership.

Godard has used another strategy in her translation of the title of Nicole Brossard's L'Amer. The word is a neologism in French which contains at least three terms: mere (mother), mer (sea), and amer (bitter). The themes of the patriarchal mother - the woman reduced to reproduction, her suffocation in this unrecognized labour and her 
subsequent tendency to suffocate her own children - pervade the first part of the book. Godard, supplementing the untranslatable wordplay of the title, whose effect rests on the "e muet," and the sound associations in French, includes a kind of "explication de texte" in her version. Her title becomes "The Sea Our Mother" + "Sea (S)mothers" + "(S)our Mothers" to finally end with:

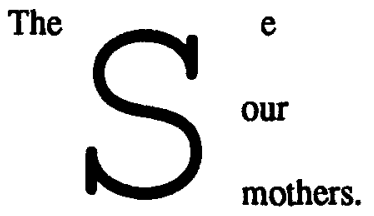

It includes the sour, smothering aspects of patriarchal motherhood in addition to the association of mer and mere, supplementing the lack of the silent "e" in English.

\section{Prefacing and Footnoting}

More recently, feminist interventions have taken on other forms. It is becoming almost routine for feminist translators to reflect on their work in a preface, and to stress their active presence in the text in footnotes. The modest, self-effacing translator, who produces a smooth, readable target language version of the original has become a thing of the past. As Godard has put it, the feminist translator seeks to flaunt her signature in italics, in footnotes, and in prefaces, deliberately womanhandling the text and actively participating in the creation of meaning (Godard, 1988, p. 50).

She is more than a conventional translator; she is the author's accomplice who maintains the strangeness of the source text, and seeks at the same time to communicate its multiple meanings otherwise "lost in translation." There is a strong didactic streak in this strategy. For example, in her preface to Nicole Brossard's These Our Mothers Godard explains the wordgames that could not be translated - the play with the silent " $\mathrm{e}$ " in French - and goes on to interpret their intention: the "e," she says, is dropped by the author in words like "laboratoir" to mark the absence of the feminine in the activities carried out there. It is removed from the title L'Amer, she continues, to "underline the 
process of articulating women's silence and moving toward a neutral grammar" (Godard, 1983, p. 7). She then indicates her supplementing activities - graphic modes, wordplays more familiar to anglophone feminists, and in a final pedagogical move draws attention to other aspects of the text which the secular (i.e. non-academic English reader) might miss: in this case, contemporary French philosophical discourse that is inscribed in the text.

The translation is marked by her interferences: for example the line "J'ai tué le ventre et fait éclater la mer" (20) becomes in the English "I have killed the womb and exploded the Sea/Sour mother" (14) , a reference to her intervention in the title. There are footnotes giving references to literary intertexts: to Camus' L'Etranger (25) and Rousseau's Confessions d'un promeneur solitaire (83). And wherever Brossard uses the word "histoire", the English His-story appears. In Lovhers, a brilliant translation of Brossard's title Amantes, an even longer translator's preface by Godard both contextualizes and interprets Brossard's text, and discusses the translation.

Marlene Wildeman's English version of Brossard's La Lettre aerienne is also prefaced and marked by the translator's interventions. Footnotes throughout the text specify intertexts that Brossard herself did not indicate : for example "le corps certain"(20) is attributed to Barthes' The Pleasure of the Text (44), and Wildeman goes so far as to even give the page numbers in the English translation of Barthes' text where this concept is developed. Page references to texts by Djuna Bames, Gertrude Stein, Luce Irigaray, Mallarmé and others are given throughout, while neither authors nor their works, let alone page references, are directly cited in the source text. Moreover, Brossard's multiple connotations are explained in copious translator's notes: for instance, the author's phrase "C'est le désir de la réplique" (136) is developed in a lengthy footnote in the English version (143). Similarly, the difficulties with neologisms like the term essentielle are discussed both in the preface and then highlighted in footnotes. In Wildeman's approach, a feminist translation becomes an educational tool supported with scholarly research. Here the question of the targetted readership is very important. 
In the preface the translator wonders whether she is translating for Canadian feminists alone and "thus flying a letter of international stature to regional airports only?" (Wildeman, 1988, p. 27) or whether she should target North American, in other words American feminists at the risk of glossing over Can/Am differences. She seems to have opted for the larger market, and prepared a text for use in Women's Studies programs anywhere in America. With Louise Forsyth's comprehensive introduction, the Québécois/Can Lit bases are covered $^{11}$.

It is perhaps this growing aspiration to international recognition, and the appeal to the US market that is partially responsible for the third strategy in feminist translation that I want to discuss here.

\section{Hijacking}

I have taken the term "hijacking" from a critic of feminist translation, a Montreal journalist (a translator himself) who attacks Susanne de Lotbinière-Harwood for her excessive interference in the translation of Lettres d'une autre by Lise Gauvin:

The translator [...] is so intrusive at times that she all but hijacks the author's work. In the introduction she tells us she intends to make her presence felt $[. .$.$] to this end she frequently$ breaks into Gauvin's work explaining what Gauvin really meant and sometimes offering the French equivalent for the English on the page. (Homel, 1990) ${ }^{12}$

11. The appeal to the American academic market is, I think, increasingly important. In a climate of "de-canonization" in the United States, and a growing fashion for marginal literatures, whether Canadian, francophone, or radical lesbian, it makes sense to target the large academic establishments and budgets. In an academic climate where women's studies programs and courses on women's writing are the rule, rather than an exception, it makes sense to practise and proclaim deliberate feminist interventions in the texts.

12. Thanks to Annie Brisset for clipping and sending me both Homel's article and de Lotbinière-Harwood's response. 
He further faults the work for its excessive footnoting, and narrow didactic approach. In his view, Gauvin's book has become an "informal textbook on contemporary Quebec culture" and been ideologically "corrected" (i.e. feminized), beyond the author's original intention. The translator responded that (a) the translation did in fact target a North American readership, including colleges and universities, and that notes explaining the referendum and tourtiere were therefore justifiable, and that (b) she worked closely with the author on the English version, from which I infer that she had her permission to "correct" the text.

Of particular interest in this work of "correction" is the translator's deliberate feminizing of the target text, which she announces in her preface as a political intervention:

Lise Gauvin is a feminist, and so am I. But I am not her. She wrote in the generic masculine. My translation practice is a political activity aimed at making language speak for women. So my signature on a translation means: this translation has used every possible translation strategy to make the feminine visible in language. Because making the feminine visible in language means making women seen and heard in the real world. Which is what feminism is all about. (De Lotbinière-Harwood, 1990, p. 9)

By making the feminine seen and heard in her translation, de Lotbinière-Harwood deliberately contravenes conventional translation practice of being see-through and silent. Her strategies include using the word Québécois-e-s wherever the generic Québécois occurred in the original - a source-language feminization tactic which she explains in her preface. She avoids other male generic terms in English although they appear in French, i.e. "la victoire de l'homme" becomes "our victory [...] over the elements"; she puts the female element first in expressions like "women and men," "her or his," and uses inverted quotation marks to emphasize some of the absurdities of conventional English, for example, the reference to women as "masters" of the kitchen.

De Lotbinière-Harwood has in fact "hijacked" the text, appropriated it, made it her own to reflect her political intentions. And 
the fact that this translation won the prize awarded for the translation of French-Canadian literature by Columbia University in 1991 further validates her strategies. In this case, the translator's collusion with the author is, I think, of secondary importance. Here the translator is writing in her own right.

\section{Theories and Effects}

It is difficult and probably unnecessary to pinpoint specific theories that have validated the feminist approach to translation. In general it could be said that the erosion of the authority of the Author/Original in post-structuralist and deconstructionist discourses of the last twenty years has certainly been of great importance, giving the translator a much freer rein with the text.

Derridean revision of key concepts in Western philosophy whose nuances were indeed "lost in translation" has stimulated renewed interest in the work of the translator ${ }^{13}$, and endowed her with the right, even the duty to "abuse" the source text ${ }^{14}$. Indeed, the entire post-structuralist project of questioning master-narratives, challenging definitive truths, and exploring relativity in meaning has forced translation to become a creative endeavour. And translators of Derrida's texts, dealing with the ambivalencies, ambiguities and multiple meanings of his writing have consistently stressed the need for creativity and experimentation in their prefaces, thus setting a new tone in translation practice. In the preface to her translation of Derrida's Dissemination, Barbara Johnson (1981), for one, calls for "strong,

13. See Derrida's "Des Tours de Babel" in Difference in Translation, ed. Joseph P. Graham, (Comell University Press, 1985). Also Derrida's retranslation of the term economy in his long footnote to "Survivre" in Parages (Paris, Galilée, 1986) and his critique of the term pharmakon based on its one-sided translation in La Dissémination (Paris, Éditions du Seuil, 1972).

14. Philip Lewis argues that only "abusive" translation can do justice to contemporary texts that pursue a critique of conventional "phallologocentric" language. See his article "The Measure of Translation Effects" in Difference in Translation, op.cit., note 17. 
forceful translation that values experimentation, tampers with usage, seeks to match the polyvalencies or plurivocities or expressive stresses of the original by producing its own" - exactly what feminist translators in Canada are doing.

Finally, the influence of second-wave feminism has been vital to feminist translation. It has endowed both Quebec feminist writers and their translators with the authority and the means to disregard Authority. With authorship and "patriarchal language" demystified, the feminist translator can dare to be a resistant, aggressive and creative writer who not only tampers with the HE/Man aspects of conventional language, but intervenes in the text in many other ways. Moreover, with recent theorists' exploitation of the lexicon of sexuality and especially sexual difference - jouissance, dissémination, invagination, hymen, and so forth - the subtle connections between gender, definitions of mimesis or fidelity in writing, and translation have become obvious, and feminist translators are striking out in at least two directions at once: at conventional language use per se and at traditional views of translation.

This is where the question of the long-term effects of feminist translation comes in, which in my view have a certain developmental if not revolutionary potential. Recent work by Lori Chamberlain ${ }^{15}$ on metaphors of translation has shown that the most traditional and misogynist conceptions of gender roles and attributes have coloured much of the discussion on translation, coding it as a passive and subservient activity that simply reproduces someone else's real work. And as we all know, the work of reproduction, of human beings or texts, though absolutely vital for literary or human endeavours, is generally underpaid, undervalued, even despised in the hierarchical structures that define our culture. Reproduction has historically been women's work; and the tropes used to describe translation, though stressing the need to maintain control of the reproduction of texts (offspring), reflect its lowliness. Indeed, the discourse on translation has consistently served to express the difference in value between the original and its "reproduction," and has routinely used metaphors of

15. Lori Chamberlain, "Gender and the Metaphorics of Translation" in Signs:Journal of Women in Culture and Society, 1988, Vol. 13, No. 3, pp. 454-472. 
rape and violence against women and of paternalistic control to maintain this difference. In so doing, traditional tropes used for translation have reflected the power relations between the sexes, and revealed the fear of the matemal (or the mother tongue), the need to protect (control) it as well as the need to retain the ownership of offspring (texts).

It is a discourse that with expressions like "les belles infidèles" has maintained the double standards based on traditional gender stereotypes according to which beautiful texts and beautiful women can only be unfaithful, and faithful texts are by definition ugly, just as ugly women (a contradiction in terms) can't help but be faithful. This metaphorics has carried on into very recent work by writers such as Serge Gavronsky who celebrates his liberation from excessive fidelity to the original as a process of "capturing, and performing rape and incest" on the text. ${ }^{16}$

It seems evident that in devising and practising creative non-traditional approaches to translation, making their presence felt in the texts and challenging their authors, feminist translators in Canada are making changes to some of these traditional views and the habitual "missionary" position assigned to translation. Translation practice, and in a teleological sense, the development of language can only stand to gain from such new approaches ${ }^{17}$. With notions of fidelity and truth, transparency and definitive meaning in translation giving way to supplementation, experimentation, interference and "transformance," and

16. Cited by Chamberlain, p. 462, from Serge Gavronsky's "The Translator: From Piety to Cannibalism" in Sub-stance, 16 (1977).

17. In a response to my oral presentation of this paper in Kingston, Jean Delisle pointed out that there seemed to be many parallels between contemporary feminist translation and the work of medieval translators. Translators of the Middle Ages were also forced to deal with neologisms, and adapt unknown terms into fluctuating and unstable target languages; moreover they played an important role in shaping and establishing new norms in language. If we extend this analogy and maintain a certain amount of optimism, we can conceive of feminist translators today having an impact on the development of gender-free, or at least gender-conscious language several centuries from now! 
with feminist consciousness inscribed in many aspects of our contemporary writing, there is thus every reason why "This evening I'm entering history without opening my legs" is a valid contemporary version of "Ce soir j'entre dans l'histoire sans relever ma jupe."

\section{Works Cited}

BENJAMIN, Walter (1977). "Die Aufgabe des Ubersetzers," Illuminationen, Frankfurt am Main, Suhrkamp.

BERSIANIK, Louky (1976). L'Euguélionne, Montreal, La Presse.

BOUCHER, Denise (1978). Les Fées ont soif, Montreal, Éditions Intermède. Translated by Alan Brown (1982). The Fairies are thirsty, Vancouver, Talonbooks.

BROSSARD, Nicole (1976). "L'Écrivain", La Nef des sorcières, Montreal, Quinze. Translated by Linda Gaboriau (1979-80), "The Writer" in Fireweed, 5-6.

(1977). L'Amèr ou le chapitre effrite, Montreal, Quinze, Reprint. (1988), Montreal, L'Hexagone . Translated (1983) by Barbara Godard, These Our Mothers or: The Disintegrating Chapter, Toronto, Coach House Press.

(1979). Brossard, ed. Les Stratégies du réel, Montreal, La barre du jour. In translation (1979), The Story So Far, Toronto, Coach House Press.

CHAMBERLAIN, Lori ((1988). "Gender and the Metaphorics of Translation," Signs: Journal of Women and Culture in Society, 13(3), pp. 454-472.

DERRIDA, Jacques (1972). La Dissémination, Paris, Seuil. (1985). "Des Tours de Babel," Difference in Translation, ed. Joseph P. Graham, Cornell University Press. 
(1986). "Survivre," Parages, Paris, Galilée.

GODARD, Barbara (1983). Preface to These Our Mothers, Toronto, Coach House Press.

(1984). "Translating and Sexual Difference," Resources for Feminist Research, 13(3), pp. 13-16.

(1988). "Theorizing FeministDiscourse/Translation,"

Mapping Literature, The Art and Politics of Translation, eds. David Homel and Sherry Simon, Montreal, Vehicule Press.

HOMEL, David (1990). "Lise Gauvin astutely explains Quebec to Outsiders," The Gazette, April 21.

JOHNSON, Barbara (1981). Preface to Dissemination, Chicago, University of Chicago Press.

LEWIS, Philip (1985). "The Measure of Translation Effects," Difference in Translation, ed. Joseph P. Graham, Cornell University Press.

DE LOTBINIÈRE-HARWOOD, Susanne (1990). Preface to Letters from Another, Toronto, Women's Press.

SABOURIN, Claude (1985). "Les Numéros "femmes" de $L a$ $B J / N B J$," Voix et images, $\mathrm{X}(2), \mathrm{pp} .125-132$.

SCOTT, Howard (1984). "Louky Bersianik's L'Euguélionne: Problems of Translating the Critique of Language in New Quebec Feminist Writing," Master's Thesis, Concordia University, Montreal.

WILDEMAN, Marlene (1988). Preface to The Aerial Letter, Toronto, Women's Press. 